\title{
Pengaruh Ukuran Perusahaan, Leverage, Dan Profitabilitas Terhadap Nilai Perusahaan
}

\author{
Rizqia Muharramah ${ }^{1}$, Mohamad Zulman Hakim ${ }^{2}$ \\ Universitas Muhammadiyah Tangerang ${ }^{1,2}$ \\ Email : rizqiam99@gmail.com
}

\begin{abstract}
Abstrak: Penelitian ini bertujuan untuk mengetahui pengaruh Ukuran Perusahaan, Leverage, dan Profitabilitas pada Nilai Perusahaan. Ukuran Perusahaan diukur dengan Logaritma Natural (Ln) Total Aset, Leverage diukur dengan Debt Equity to Ratio (DER), Profitabilitas diukur dengan Return On Asset (ROA) dan Nilai Perusahaan diukur dengan Price to Book Value (PBV). Populasi dalam penelitian ini ini adalah semua perusahaan Property pada sektor Property, Real estate, dan Konstruksi yang terdaftar di Bursa Efek Indonesia (BEI)periode 2016-2019. Total sampel yang diuji adalah 8 perusahaan yang dipilih dengan teknik purposive sampling. Teknik analisis data menggunakan regresi data panel dengan program Eviews 9.0. Hasil dari penelitian ini menunjukkan bahwa Ukuran Perusahaan mempengaruhi Nilai Perusahaan. Sementara Leverage dan Profitabilitas tidak mempengaruhi Nilai Perusahaan.
\end{abstract}

Kata Kunci: Nilai Perusahaan, Ukuran Perusahaan, Leverage, Profitabilitas

Tujuan perusahaan salah satunya untuk memaksimalkan nilai perusahaan atau kekayaan bagi pemegang saham. Memaksimalkan nilai perusahaan dinilai lebih tepat sebagai tujuan suatu perusahaan sebab memaksimalkan nilai perusahaan berarti memaksimalkan nilai sekarang dari semua keuntungan yang akan diterima oleh pemegang saham dimasa yang akan datang.

Mengutip dari Bursa Efek Indonesia (BEI), Indeks pada sektor properti tercatat $0,77 \%$ ke level 491,948 . Bahkan turun $5,67 \%$ dalam tahun berjalan. Hal ini diakibatkan oleh kurangnya minat masyarakat untuk membeli properti, masyarakat lebih mementingkan untuk membeli kebutuhan pokok pribadinya. Oleh sebab itu hal ini yang menjadikan penyebab lambatnya investasi di sektor properti. Berita yang bersumber dari CNN Indonesia menyebutkan kondisi yang semakin buruk yang disebabkan oleh harga properti yang semakin tinggi, sehingga masyarakat kesulitan mengejar harga properti yang setiap tahunnya naik. Terbukti indeks sektor properti sangat anjlok jika dilihat sejak awal tahun 2017. Pada awal bulan Januari 2017 indeks sektor berada pada level 521, 547 yang artinya indeks sektor properti merosot sebesar 5, 67\%.

Ukuan Perusahaan adalah suatu skala perusahaan yang dapat dikelompokkan menjadi besar kecilnya perusahaan berdasarkan total aktiva, total penjualan dan nilai saham (Novari dan Lestari, 2016). Menurut penelitian dari (Rudangga dan Sudiartha, 2016) menunjukkan bahwa Ukuran Perusahaan berpengaruh positif signifikan terhadap Nilai Perusahaan. Menurut penelitian oleh (Eka Indriyani (2017) menunjukkan bahwa Ukuran Perusahaan tidak berpengaruh signifikan terhadap Nilai Perusahaan.

Leverage adalah suatu resiko keuangan yang digunakan untuk mengukur pendanaan suatu perusahaan yang berasal dari penggunaan 
hutang. Menurut penelitian dari (Rudangga dan Sudiartha, 2016) menunjukkan bahwa Leverage berpengaruh positif signifikan terhadap Nilai Perusahaan. Menurut penelitian dari (Novari dan Lestari, 2016) menunjukkan bahwa Leverage tidak berpengaruh signifikan terhadap Nilai Perusahaan.

Profitabilitas adalah suatu kemampuan perusahaan untuk mendapatkam keuntungan dalam suatu periode tertentu, serta menjadi alat ukur efektivitas operasional keseluruhan perusahaan. Menurut penelitian dari (Rudangga dan Sudiartha, 2016) menunjukkan bahwa Profitabilitas berpengaruh positif signifikan terhadap Nilai Perusahaan. Menurut penelitian dari (Tarima, Parengkuan dan Untu, 2016) menunjukkan bahwa Profitabilitas tidak berpengaruh signifikan terhadap Nilai Perusahaan.

Teori sinyal memiliki keterkaitan pada variabel ukuran perusahaan. Perusahaan besar menunjukkan perusahaan mengalami perkembangan sehingga akan memberikan sinyal baik kepada pihak luar seperti para investor yang memberikan respon positif pada perusahaan tersebut.

Teori sinyal juga memiliki keterkaitan pada variabel Profitabilitas, yaitu ketika perusahaan dengan tingkat profitabilitas tinggi, akan menggunakan informasi keuangannya untuk mengirim sinyal kepada pasar. Laporan keuangan yang memiliki tingkat profitabilitas tinggi menunjukkan prospek perusahaan baik, sehingga investor akan merespon positif sinyal tersebut dan nilai perusahaan akan meningkat.

Adapun tujuan dalam penelitian ini adalah Untuk membuktikan secara empiris pengaruh Ukuran Perusahaan, Leverage, dan Profitabilitas terhadap Nilai Perusahaan.

\section{METODE}

Jenis metode penelitian ini yang dipergunakan adalah jenis metode penelitian kuantitatif. Dikatakan kuantitatif karena data penelitian berupa angka-angka dan analisis menggunakan statistik (Sugiyono, 2012). Penelitian ini menggunakan data kuantitatif berdasarkan data sekunder yang diperoleh dari laporan keuangan tahunan yang terdaftar di Bursa Efek Indonesia (BEI) pada sektor Property, Real Estate dan Konstruksi yang diperoleh dari website https://www.idx.co.id/ tahun 2017-2019.

Pemilihan sampel dilakukan pada semua populasi yang memenuhi kelengkapan data. Metode yang digunakan umtuk pengumpulan sampel adalah berdasarkan metode Purposive Sampling. Metode ini merupakan metode pengumpulan data sampel yang menyajikan informasi yang lengkap dan menggunakan pertimbangan dan kriteria tertentu. Dalam penelitian ini, teknik analisis data yang digunakan yaitu analisis regresi data panel dengan bantuan software pengolah data eviews 9.0. 


\section{HASIL}

1. Analisis Statistik Deskriptif

Hasil Analisis statistik deskriptif pada masing-masing variabel yaitu PBV, UP, DER, dan ROA adalah sebagai berikut:

Tabel 1. Analisis Statistik Deskriptif

Date: $11 / 21 / 20$

Time: $18: 11$

Sample: 20162019

\begin{tabular}{lcccc}
\hline \hline & PBV & UP & DER & ROA \\
\hline \hline Mean & 16143.09 & -971.6563 & 7555.781 & 394.1563 \\
Median & 11580.00 & 1458.000 & 6007.500 & 360.0000 \\
Maximum & 49430.00 & 15980.00 & 15842.00 & 1124.000 \\
Minimum & 720.0000 & -26311.00 & 555.0000 & 3.000000 \\
Std. Dev. & 14109.15 & 12671.54 & 4355.399 & 279.4939 \\
Skewness & 0.667597 & -0.526157 & 0.494281 & 0.365230 \\
Kurtosis & 2.385722 & 2.052392 & 2.130997 & 2.743572 \\
& & & & \\
Jarque-Bera & 2.880105 & 2.673766 & 2.309893 & 0.799103 \\
Probability & 0.236915 & 0.262663 & 0.315074 & 0.670621 \\
& & & & \\
Sum & 516579.0 & -31093.00 & 241785.0 & 12613.00 \\
Sum Sq. Dev. & $6.17 \mathrm{E}+09$ & $4.98 \mathrm{E}+09$ & $5.88 \mathrm{E}+08$ & 2421622. \\
Observations & 32 & 32 & 32 & 32
\end{tabular}

Sumber : Data Diolah

Pada tabel diatas, dapat dejelaskan bahwa jumlah data yang digunakan dalam penelitian ini sebanyak 32 data.

Nilai Mean terbesar dialami oleh variable PBV, yaitu sebesar 16143.09 sementara variable ROA memiliki nilai Mean yang paling kecil, yaitu sebesar 394.1563.

Nilai Median terbesar dialami oleh variable PBV, yaitu sebesar 11580.00 sementara variable UP memiliki nilai Median yang paling kecil, yaitu sebesar 1458.000 .

Nilai Maximum terbesar dialami oleh variable PBV, yaitu sebesar 49430.00 sementara variable ROA memiliki nilai Maximum yang paling kecil yaitu 1124.000.

Nilai Minimum terbesar dialami oleh variable PBV, yaitu sebesar 720.000 sementara variable ROA memiliki nilai Minimum yang paling kecil yaitu 3.000000 .

Nilai Std. Dev terbesar dialami oleh variable PBV, yaitu sebesar 14109.15 yang berarti bahwa variable PBV memiliki tingkat risiko yang lebih tinggi mengalami perubahan dibandingkan variable - variable yang lain selama periode penelitian. Sementara variable ROA memiliki nilai Std. Dev yang paling kecil yaitu 279.4939. Hal ini menunjukkan bahwa variabel 
DER dan UP selama periode penelitian mengalami perubahan yang tidak terlalu fluktuatif.

Skewness dari suatu distribusi simetris (distribusi normal) adalah 0 (nol). Variable PBV, UP, DER dan ROA memiliki nilai di sekitar o (nol) maka asimetri distribusi data sekitar mean bersifat normal.

Kurtosis mengukur ketinggian suatu distribusi. Kurtosis suatu data berdistribusi normal adalah 3. Untuk variable PBV, UP, DER dan ROA memiliki nilai kurtosis kurang dari 3 yang berarti bahwa ketinggian distribusi data normal.

2. Pemilihan Model Regresi Data Panel

a. Uji Chow

Redundant Fixed Effects Tests

Tabel 2. Uji Chow

Equation: EQ01

Test cross-section fixed effects

\begin{tabular}{lrrr}
\hline \hline Effects Test & Statistic & d.f. & Prob. \\
\hline \hline Cross-section F & 6.152268 & $(7,21)$ & 0.0005 \\
Cross-section Chi-square & 35.692463 & 7 & 0.0000
\end{tabular}

Sumber : Data Diolah

Berdasarkan hasil perhitungan nilai (Prob.) cross-section $\mathrm{F}$ dan cross-section chi-square $<\alpha(0,05)$, maka dapat disimpulkan bahwa Fixed Effect Model (FEM) lebih layak dibandingkan Common Effect Model (CEM).

b. Uji Hausman

Tabel 3. Uji Hausman

Correlated Random Effects - Hausman Test

Equation: EQ01

Test cross-section random effects

\begin{tabular}{lrrr}
\hline \hline Test Summary & $\begin{array}{l}\text { Chi-Sq. } \\
\text { Statistic }\end{array}$ & Chi-Sq. d.f. & Prob. \\
\hline \hline Cross-section random & 7.708818 & 3 & 0.0524 \\
\hline \hline
\end{tabular}

Sumber : Data Diolah

Berdasarkan hasil perhitungan diatas nilai Probabilitas Cross-Section random > 0,05 maka dapat disimpulkan bahwa Random Effect Model (REM) ) lebih layak digunakan dibandingkan lebih layak digunakan dibandingkan Fixed Effect Model (FEM).

c. Uji Lagrange Multiplier

\section{Tabel 4. Uji Lagrange Multiplier}

Lagrange Multiplier Tests for Random Effects

Null hypotheses: No effects

Alternative hypotheses: Two-sided (Breusch-Pagan) and one-sided (all others) alternatives

$\underline{\underline{ }}=\underline{\text { Cross-section }}=\underline{\begin{array}{c}\text { Test Hypothesis } \\ \text { Time }\end{array}}=$




\begin{tabular}{|c|c|c|c|}
\hline Breusch-Pagan & $\begin{array}{l}5.188363 \\
(0.0227)\end{array}$ & $\begin{array}{l}1.253571 \\
(0.2629)\end{array}$ & $\begin{array}{l}6.441934 \\
(0.0111)\end{array}$ \\
\hline Honda & $\begin{array}{l}2.277798 \\
(0.0114)\end{array}$ & $\begin{array}{c}-1.119630 \\
--\end{array}$ & $\begin{array}{l}0.818949 \\
(0.2064)\end{array}$ \\
\hline King-Wu & $\begin{array}{l}2.277798 \\
(0.0114)\end{array}$ & $\begin{array}{c}-1.119630 \\
--\end{array}$ & $\begin{array}{l}0.310852 \\
(0.3780)\end{array}$ \\
\hline Standardized Honda & $\begin{array}{l}3.518862 \\
(0.0002)\end{array}$ & $\begin{array}{c}-0.887056 \\
--\end{array}$ & $\begin{array}{c}-1.407014 \\
--\end{array}$ \\
\hline Standardized King-Wu & $\begin{array}{l}3.518862 \\
(0.0002)\end{array}$ & $\begin{array}{c}-0.887056 \\
--\end{array}$ & $\begin{array}{c}-1.879684 \\
--\end{array}$ \\
\hline Gourierioux, et al.* & -- & -- & $\begin{array}{c}5.188363 \\
(<0.05)\end{array}$ \\
\hline $\begin{array}{r}\text { Mixed chi-square asympto } \\
1 \% \\
5 \% \\
10 \%\end{array}$ & $\begin{array}{r}\text { ritical value } \\
7.28 \\
4.32 \\
2.95\end{array}$ & & \\
\hline
\end{tabular}

Sumber : Data Diolah

Berdasarkan hasil perhitungan diatas nilai Probabilitas Cross-Section Breusch-Pagan < 0,05 maka dapat disimpulkan bahwa Random Effect Model (REM) ) lebih layak digunakan dibandingkan lebih layak digunakan dibandingkan Common Effect Model (CEM).

3. Uji Hipotesis

a. Analisis Koefisien Determinasi

Analisis Koefisien Determinasi penelitian ini menggunakan dasar $\mathrm{R}$ square Tabel 5. Koefisien Determinasi

$\begin{array}{ll}\text { R-squared } & 0.835010 \\ \text { Adjusted R-squared } & 0.817333\end{array}$

Sumber : Data Diolah

Pada table diatas menunjukkan bahwa nilai Adjusted R-squared sebesar 0.817333 yang artinya bahwa variasi perubahan naik turunnya PBV dapat dijelaskan oleh UP, DER dan ROA sebesar 81,73\%, sementara sisanya yaitu sebesar $18,27 \%$ dijelaskan oleh variable variable lain yang tidak diteliti dalam penelitian ini.

b. Uji $\mathrm{F}$

Tabel. 6 Uji F

\begin{tabular}{|lc|}
\hline F-statistic & 47.23578 \\
Prob(F-statistic) & 0.000000 \\
\hline
\end{tabular}

Sumber : Data Diolah

Pada output diatas menunjukkan bahwa nilai $F$-statistic sebesar 47.23578, sementara $F$ tabel dengan tingkat $\alpha=5 \%$, df $1(\mathrm{k}-1)=3$ dan df2 $(n-k)=28$ didapat nilai $F$ tabel sebesar 2,95. Dengan demikian F-statistic (47.23578) > F tabel $(2,95)$, dan nilai Prob (F- statistic) $0.000000<0,05$ maka dapat disimpulkan bahwa Ha diterima, maka demikian dapat 
disimpulkan bahwa variable independen dalam penelitian ini yang terdiri dari UKURAN PERUSAHAAN (X1), LEVERAGE (X2) dan PROFITABILITAS (X3) secara bersama-sama memiliki pengaruh terhadap Nilai Perusahaan.

c. Uji T

Date: $11 / 21 / 20$ Time: $18: 18$

Tabel. 7 Uji t

Sample: 20162019

Periods included: 4

Cross-sections included: 8

Total panel (balanced) observations: 32

Swamy and Arora estimator of component variances

\begin{tabular}{crrrr}
\hline \hline Variable & Coefficient & Std. Error & t-Statistic & Prob. \\
\hline \hline C & 18662.48 & 3258.136 & 5.727963 & 0.0000 \\
UP & 1.192734 & 0.094125 & 12.67177 & 0.0000 \\
DER & -0.427613 & 0.339416 & -1.259849 & 0.2181 \\
ROA & 4.745555 & 3.661873 & 1.295936 & 0.2056 \\
\hline
\end{tabular}

Sumber : Data Diolah

1) Nilai t-statistic Ukuran Perusahaan (UP) sebesar 12.67177 sementara $t$ Tabel dengan tingkat $\alpha=5 \%$, df $(n-k)=28$ didapat nilai t Tabel sebesar 2.04481. Dengan demikian t-statistic UP > t Tabel (2.04481) dan nilai Prob. $0.0000<0,05$ maka dapat disimpulkan bahwa variable Ukuran Perusahaan ( UP ) dalam penelitian ini memiliki pengaruh terhadap Nilai Perusahaan. Dengan demikian, $\mathrm{H} 1$ dalam penelitian ini diterima.

2) Nilai t-statistic Leverage (DER) sebesar 1.259849 sementara t Tabel dengan tingkat $\alpha=5 \%$, df $(n-k)=28$ didapat nilai $t$ Tabel sebesar 2.04481. Dengan demikian t-statistic DER < t Tabel (2.05183) dan nilai Prob. $0.2181>0,05$ maka dapat disimpulkan bahwa variable Leverage (DER) dalam penelitian ini tidak memiliki pengaruh terhadap Nilai Perusahaan.. Dengan demikian, H2 dalam penelitian ini ditolak.

3) Nilai t-statistic Profitabilitas (ROA) sebesar 1.295936, sementara t Tabel dengan tingkat $\alpha=5 \%$, df $(n-k)=28$ didapat nilai $t$ Tabel sebesar 2.04481. Dengan demikian t-statistic ROA < t Tabel (2.04481) dan nilai Prob. $0.2056>0,05$ maka dapat disimpulkan bahwa variable Profitabilitas (ROA) dalam penelitian ini tidak memiliki pengaruh terhadap Nilai Perusahaan. Dengan demikian, H3 dalam penelitian ini ditolak.

Berdasarkan hasil Uji Hipotesis dan Koefisien Determinasi diatas diperoleh hasil sebagai berikut :

\section{Pengaruh Ukuran Perusahaan terhadap Nilai Perusahaan}

Hipotesis pertama yang diajukan pada penelitian ini adalah bahwa Ukuran Perusahaan berpengaruh positif signifikan terhadap Nilai Perusahaan, sehingga hipotesis diterima. Hal ini dapat ditunjukkan pada 
nilai Ukuran Perusahaan yaitu sebesar 12.67177 sementara t Tabel dengan tingkat $\alpha=5 \%$, df $(n-k)=28$ didapat nilai t Tabel sebesar 2.04481. Dengan demikian t-statistic UP > t Tabel (2.04481) dan nilai Prob. 0.0000 $<0,05$ maka dapat disimpulkan bahwa variable Ukuran Perusahaan (UP) dalam penelitian ini memiliki pengaruh terhadap Nilai Perusahaan. Dengan demikian, $\mathrm{H} 1$ dalam penelitian ini diterima.

\section{Pengaruh Leverage terhadap Nilai Perusahaan}

Hipotesis kedua yang diajukan pada penelitian ini adalah bahwa Leverage (DER) berpengaruh negatif signifikan terhadap Nilai Perusahaan, sehingga hipotesis ditolak. Hal ini dapat ditunjukkan pada nilai Leverage (DER) yaitu sebesar 1.259849 sementara t Tabel dengan tingkat $\alpha=5 \%$, df $(n-k)=28$ didapat nilai $t$ Tabel sebesar 2.04481 . Dengan demikian t-statistic DER < t Tabel (2.05183) dan nilai Prob. $0.2181>0,05$. Maka dapat disimpulkan bahwa variable Leverage dalam penelitian ini tidak memiliki pengaruh terhadap Nilai Perusahaan. Dengan demikian, $\mathrm{H} 2$ dalam penelitian ini ditolak.

\section{Pengaruh Profitabilitas terhadap Nilai Perusahaan}

Hipotesis ketiga yang diajukan pada penelitian ini adalah bahwa Profitabilitas tidak berpengaruh signifikan terhadap Nilai Perusahaan, sehingga hipotesis ditolak. Hal ini dapat ditunjukkan pada nilai Profitabilitas (ROA) yaitu sebesar 1.295936, sementara t Tabel dengan tingkat $\alpha=5 \%$, df $(n-k)=28$ didapat nilai $t$ Tabel sebesar 2.04481 . Dengan demikian t-statistic ROA < t Tabel (2.04481) dan nilai Prob. $0.2056>0,05$. Maka dapat disimpulkan bahwa variable Profitabilitas dalam penelitian ini tidak memiliki pengaruh terhadap Nilai Perusahaan. Dengan demikian, H3 dalam penelitian ini ditolak.

\section{KESIMPULAN}

Penelitian ini bertujuan untuk mengetahui pengaruh Ukuran Perusahaan, Leverage, dan Profitabilitas terhadap Nilai Perusahaan yang terdaftar di Bursa Efek Indonesia (BEI) periode 2016-2019. Berdasarkan Uji yang telah dilakukan oleh penelit, maka terdapat beberapa kesimpulan yang dapat diambil, yaitu:

1. Ukuran Perusahaan memiliki pengaruh terhadap Nilai Perusahaan sektor Property, Real Estate, dan Konstruksi yang terdaftar di Bursa Efek Indonesia (BEI) periode 2016-2019.

2. Leverage tidak memiliki pengaruh terhadap Nilai Perusahaan sektor Property, Real Estate, dan Konstruksi yang terdaftar di Bursa Efek Indonesia (BEI) periode 2016-2019.

3. Profitabilitas tidak memiliki pengaruh terhadap Nilai Perusahaan sektor Property, Real Estate, dan Konstruksi yang terdaftar di Bursa Efek Indonesia (BEI) periode 2016-2019.

\section{DAFTAR PUSTAKA}

Rudangga, I. G. N. G., \& Sudiarta, G. M. (2016). Pengaruh ukuran perusahaan, leverage, dan profitabilitas terhadap nilai 
perusahaan. E-Jurnal Manajemen Universitas Udayana, 5(7).

Novari, P. M., \& Lestari, P. V. (2016). Pengaruh ukuran perusahaan, leverage, dan profitabilitas terhadap nilai perusahaan pada sektor properti dan real estate. E-Jurnal Manajemen Universitas Udayana, 5(9).

Tania, R. N. (2019). PENGARUH UKURAN PERUSAHAAN, LEVERAGE, PROFITABILITAS DAN KEBIJAKAN DIVIDEN TERHADAP NILAI PERUSAHAAN (STUDI PADA PERUSAHAAN LQ45 YANG TERDAFTAR DI BURSA EFEK INDONESIA 2014-2017) (Doctoral dissertation, UNIVERSITAS NEGERI YOGYAKARTA).

Indriyani, E. (2017). Pengaruh ukuran perusahaan dan profitabilitas terhadap nilai perusahaan. Akuntabilitas: Jurnal IImu Akuntansi, 10(2), 333-348.

Hasibuan, V., Dzulkirom AR, M., \& Wi Endang NP, N. G. (2016). Pengaruh leverage dan profitabilitas terhadap nilai perusahaan (Studi pada perusahaan property dan real estate yang terdaftar di Bursa Efek Indonesia periode tahun 2012-2015). Jurnal Administrasi Bisnis, 39(1), 139-147.

Analisa, Y., \& Wahyudi, S. (2011). pengaruh ukuran perusahaan, leverage, profitabilitas dan kebijakan dividen terhadap nilai perusahaan (studi pada perusahaan manufaktur yang terdaftar di bursa efek indonesia tahun 2006-2008) (Doctoral dissertation, Universitas Diponegoro).

Sujoko, S. (2007). Pengaruh Kepemilikan Saham, Leverage, Terhadap Nilai Perusahaan. Jurnal Manajemen dan Kewirausahaan, Nomor, 19.

Nofrita, R. (2013). Pengaruh Profitabilitas terhadap Nilai Perusahaan dengan Kebijakan Deviden sebagai Variabel Intervening (Studi Empiris pada Perusahaan Manufaktur yang Terdaftar di BEI). Jurnal Akuntansi, 1(1). 